\title{
視空間ワーキングメモリの操作・生成機能が視覚情報のリハー サルに及ぼす効果
}

\author{
$\bigcirc$ 西原進吉 ${ }^{1} \cdot$ 眞嶋良全 ${ }^{2}$ \\ $\left({ }^{1}\right.$ 北海道大学大学院文学研究科 $\cdot{ }^{2}$ 北星学園大学 $)$ \\ キーワード : 視空間ワーキングメモリ, リハーサル機能, inner Scribe
}

The effects of manipulate and generate functions on the visual rehearsal task

Shinkichi NISHIHARA ${ }^{1}$ and Yoshimasa MAJIMA ${ }^{2}$

( ${ }^{1}$ Hokkaido University, ${ }^{2}$ Hokusei Gakuen University.)

Key Words: visuo-spatial working memory, rehearsal functions, inner scribe

\section{目 的}

本研究では，視空間ワーキングメモリモデルにおける「リ ハーサル」機能に焦点をあて，リハーサル機能が，視空間ワ 一キングメモリ内のその他の機能とどのように関係するのか という問題を検討する。

近年のワーキングメモリ研究では，それぞれのコンポーネ ントの機能を妨害する干渉課題の開発により，コンポーネン トが細分化され，それに伴って機能や特徴に関しても徐々に 明らかにされつつある。その中で, 特に視空間情報のリハー サルに関しては, 視空間ワーキングメモリ内に仮定された Inner Scribeがその機能を担うのではないかと主張されてい る(Logie, 1995)。

一方, Inner scribeには視空間情報の操作に代表される, リハーサル以外の機能も付与されており, 同機能とリハーサ ル機能との関係は必ずしも明確にされていない。また，ヒト が情報の維持を行うような場合，できる限り様々方略を用い るであろうことが予想されるが，このような観点に立脚した 場合, リハーサル機能が視空間ワーキングメモリ内のその他 の機能とどのように関係するのかということを明らかにする ことが重要であると思われる。

そこで本研究では, 上記の問題を明らかにするための第 1 段階として，視空間ワーキングメモリが有している諸機能の うちの「操作」「生成」機能に着目し，これらの機能が視空間 情報のリハーサルにおいて有効に機能するか否かを検討する。 方 法

実験参加者 大学生 17 名（男性 3 名、女性 14 名）が実験に 参加した。

刺激 象形文字が視覚刺激として用いられた。具体的には, 実験参加者の大学生がその意味を理解できない, ウガリット 文字，フェニキア文字，デーヴァナーガリー文字からそれぞ れ 3 種類の文字が用意された（図 1 )。使用された文字刺激に 関しては，事前に難易度の調整が行われた。

課題と手続き 課題は練習フェーズ, 本課題, 事後質問の 3 セッションで構成された。練習フェーズでは, 実験に関する 教示と, 提示される視覚オブジェクトに対するリハーサル方 法に関する説明が行われた。本課題では, 視覚情報再生課題 が実施された。視覚情報再生課題では, 参加者の前に設置さ れたスクリーン上に, 10 秒間視覚刺激が提示された。参加者 はスクリーン上に投影された視覚刺激に対して, 積極的な介 入操作を行いながら視覚刺激消失後 90 秒間保持しなければ ならなかった。リハーサルの種類は 3 つ存在した。1つは inner scribeの「操作」機能を使うであろうと想定されるも のであり，視覚刺激をわずかに「ゆらす」ことが求められた。 もう 1 つは, 中央実行形が少なからず関与する「生成」機能
を使うと想定されるものであり，提示された視覚刺激に特定 の形（黒い半円）を新たに「付け加える」ことが求められた。 最後の 1 つは, 統制条件であり, 参加者は提示された視覚刺 激に対して，少なくとも上記のような介入操作は行わないこ とが求められた。3 種のリハーサル条件の実施順序は参加者 毎にランダムであった。一方, 各条件内での刺激種類の提示 順は常にデーヴァナーガリー文字 (DV), ウガリット文字 (UG), フェニキア $(\mathrm{PH})$ 文字であった。実験参加者は，90 秒の保持時 間後, 保持していた形を紙の上に再生することが求められた。

\section{दो 拜正 $K$ 习}

図 1 使用文字種例

(左から，デーヴァナーガリー， ウガリット，フェニキア） 結 果

使用したす心゙ての文字毎の特徵の数を数值化し，紙に描か れた図において, 上記の特徴がどれだけ再生されているかを 採点した。そこで得られた得点は, 各文字における特徽の最 大数で除算することによって特徴再生率とした。この特徴再 生率に対して被験者内 2 要因（リハーサル方略 $\times$ 文字種）の 分散分析を実施した。

その結果, リハーサル方略条件と文字種条件間に有意な交 互作用が観察された $(F(4,64)=2.626, p<.05)$ 。下位検定の結 果, デーヴァナーガリー文字 (DV) を提示した場合においての み, リハーサル方略に関する有意傾向が確認され

$(F(2,96)=2.615, p<.10)$, 統制条件と比較して操作条件にお いて成績が良いという結果が得られた $(t(96)=2.279, p<.03$, 困 2 )。

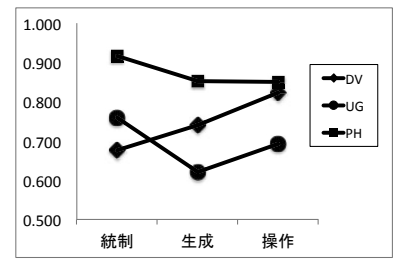

図 2 リハーサルの種類別特徴再生率

考 察

リハーサルの種類の違いが，視覚情報リハーサルに影響を 及ぼすという統計的に有意な結果は得られなかった。しかし, 有意傾向にとどまってはいるものの, デーヴァナーガリー文 字に関して, inner scribe の機能である「操作」に関連した 視覚情報を「ゆらす」操作が，視覚情報リハーサルにおいて 有効である可能性が示された。 